\title{
Effect of Carrageenan Addition on the Yield and Functional Properties of Charqui (Jerked Beef)
}

\author{
Carlos Eduardo Rocha Garcia ${ }^{1,2}$, FabioYamashita ${ }^{1}$, Elza Youssef Youssef ${ }^{1}$, Sandra Helena \\ Prudencio $^{1}$ and Massami Shimokomaki ${ }^{1,3 *}$ \\ ${ }^{1}$ Departamento de Ciência e Tecnologia dos Alimentos; Universidade Estadual de Londrina; C.P.: 6001; 86051- \\ 900; Londrina - PR - Brasil. ${ }^{2}$ Departamento de Farmácia; Universidade Federal do Paraná; 80210-170, Curitiba \\ - PR - Brasil. ${ }^{3}$ Departamento de Pesquisa e Pós-Graduação; Universidadde Tecnológica Federal do Paraná; Av \\ dos Pioneiros, 3131; 86036-6130; Londrina - PR - Brasil
}

\begin{abstract}
The objective of this work was to evaluate the application of carrageenan $(C A R)$ to improve the functional properties of the jerked beef (JF) and to increase its processing yield. JB produced from Vastus lateralis with CAR $(1.0 \%)$ at $25^{\circ} \mathrm{C}$ and $\mathrm{NaCl}(15.0 \%)$ had approximately $15.0 \%$ higher moisture and a $32.0 \%$ higher processing yield in comparison to the control samples. JB-CAR presented shear force approximately 5.0 and $20 \%$ lower in the samples uncooked salted and desalted cooked, respectively, and sensorial acceptance above $80 \%$. The results demonstrated the possibility of applying carrageenan to jerked beef in order to obtain an increase in the processing yield and a tender product while maintaining the sensorial quality and its intermediate-moisture meat product nature.
\end{abstract}

Key words: additives, hydrocolloids, meat products, texture

\section{INTRODUCTION}

Charqui meat $(\mathrm{CM})$ is a typical Brazilian meat product, processed by the traditional techniques by applying the salt and drying in the sun. This technology eliminates the need to use refrigeration in order to preserve it microbiologically. Although $\mathrm{CM}$ processing is still based on an old practice, this technique follows the current principles of a food processing technology, known as hurdle technology, put forward by Leistner and Gorris (1995). After the salting and drying steps, the final product has a water activity $\left(\mathrm{a}_{\mathrm{w}}\right)$ of $0.70-0.75$, classifying it as an intermediate-moisture meat product (Shimokomaki et al. 1998). The observed water activity is the result of chemical reaction equilibrium among the $\mathrm{NaCl}$, protein, and moisture available within the meat system (Shimokomaki et al. 1998). New technological advances that have been introduced, such as the addition of cured salt and vacuum packaging, create additional hurdles which microorganisms are unable to overcome, thus providing increasing food safety. The product processed with these additional hurdles is commercially known as jerked beef (JB) (Lara et al. 2003). The Brazilian Agricultural Ministry has established legal regulations for the chemical composition of commercial JB: maximum moisture of $55.0 \%$, $18.3 \%$ ash, $50 \mathrm{ppm}$ of sodium nitrite, maximum $\mathrm{a}_{\mathrm{w}}$ value of 0.78 , and application of vacuum packaging (Brasil 2000). In a work to demonstrate the fermented nature of the product; $S$. carnosus was isolated during the processing and applied as a

*Author for correspondence: mshimo@uel.br 
starter culture (Pinto et al. 2002). Despite all the qualities described above, JB has been shown not to be a tender meat product. Charqui meat texture is affected by a multitude of factors, in particular by the dynamic process of myofibril proteins promoting the biochemical events such as the binding of water molecules. The amount of bound water ultimately or rather the higher concentration of myofibrils proteins, dictates the final charqui meat texture (Youssef et al. 2007).

Hydrocolloids such as carrageenan (CAR) are primarily used to enhance the functional properties of foods. CAR has the ability to form aqueous dispersions, and also to retain water. It is applied as a food thicker and stabilizer and has successfully been used as a fat substitute (Keeton 1994). CAR is a polysaccharide, composed of sulfated polymers of galactose and anhydride galactose, extracted from the red algae. Commercially available CAR consists of three main fractions: kappa, iota, and lambda, and only the last fraction is not capable of forming a gel (Giese 1992). The objective of this work was to evaluate the application of carrageenan to JB in order to improve its functional properties by retaining the water intramuscularly, thus making the product less tougher and increasing the JB processing yield.

\section{MATERIALS AND METHODS}

\section{Samples preparation}

For each treatment, Vastus lateralis $m$ beef samples in triplicate were cut into cubes of approximately $50 \times 50 \times 50 \mathrm{~mm}$, totalizing one hundred grams each and kept at $4^{\circ} \mathrm{C}\left( \pm 1^{\circ} \mathrm{C}\right)$. The CAR was prepared with $50.0 \%$ kappa and $50 \%$ iota fractions of food grade quality (Globalfood, São Paulo, Brazil).

\section{Jerked beef processing}

Figure 1 shows the step-by-step fluxogram of JB processing with the CAR (JB-CAR). The CAR $(0.5$ or $1.0 \%)$ was diluted in brine heated at two temperatures $\left(25\right.$ or $\left.70^{\circ} \mathrm{C}\right)$. The brine $\mathrm{NaCl}$ concentrations (CAR-brine) were 0.0, 5.0, 10.0, and $15.0 \%$. It was injected manually into $60 \%$ $(\mathrm{v} / \mathrm{w})$ in relation to the fresh meat samples. Sodium nitrite was also dissolved in brine in concentrations of $50 \mathrm{ppm}$. The injected meat samples were subsequently kept immersed in excess of CAR-brine injected for 0 to $24 \mathrm{~h}$ at $4^{\circ} \mathrm{C}$ $\left( \pm 1^{\circ} \mathrm{C}\right)$. Finally, the meat samples were submitted to dry salting as described by Shimokomaki et al. (1998) and samples were kept at $25^{\circ} \mathrm{C}$ with daily changes of rock salt for four days. Excess salt was removed manually from the meat surface and it was then stored at $25^{\circ} \mathrm{C}$ in vacuum packaging for up to 60 days.

\section{Effect of $\mathrm{CAR}, \mathrm{NaCl}$ concentrations and brine temperatures on JB processing yield}

The samples of JB-CAR were prepared according to the factorial design ANOVA $(2 \times 2 \times 4)$ by varying the temperature values $\left(25\right.$ and $\left.70^{\circ} \mathrm{C}\right)$ of the CAR-brine, CAR concentrations $(0.5$ and $1.0 \%$ in relation to the raw material weight), and brine $\mathrm{NaCl}$ concentration $(0.0,5.0,10.0$ and $15.0 \%)$.

\section{Effect of CAR-brine immersion time on JB processing yield}

The fresh meat time lengths of immersion in the CAR-brine solution necessary to obtain the best processing yield were investigated in the products according to the fluxogram described in Figure 1. This immersion time varied from 0 to $24 \mathrm{~h}$. In this experiment, the CAR-brine was injected only at $25^{\circ} \mathrm{C}$. At every $2 \mathrm{~h}$, triplicate $\mathrm{JB}$ samples were collected and submitted for salting (steps 3 to 7 , Fig. 1), before the yield calculations were performed. Chemical composition, $a_{w}$ and JB-CAR
processing yield

The samples resulting from the highest processing yield were evaluated in relation to the proximate chemical composition and $\mathrm{a}_{\mathrm{w}}$. Moisture, ash, protein, lipid and $\mathrm{pH}$ values were determined in raw material, JB control and JB-CAR according to AOAC methods (1995). Moisture and ash were determined throughout the processing; the water activity values were monitored by the AqualabDecagon Devices Inc. equipment, model CX-2 (Ann Arbor, MI, USA) at $25^{\circ} \mathrm{C}\left( \pm 1^{\circ} \mathrm{C}\right)$. The processing yield was expressed as a mass percentage of JB-CAR produced in relation to the initial mass of fresh meat. All the measurements were carried out in triplicate 
Step 1. Deboned raw material

$$
\text { ( } \text {. lateralis) }
$$

Step 2. Injection of brine $(0,5.0,10.0$ or

$15.0 \% \mathrm{NaCl}+0.5$ or $1.0 \%$ carrageenan at 25 or $70^{\circ} \mathrm{C}$ )

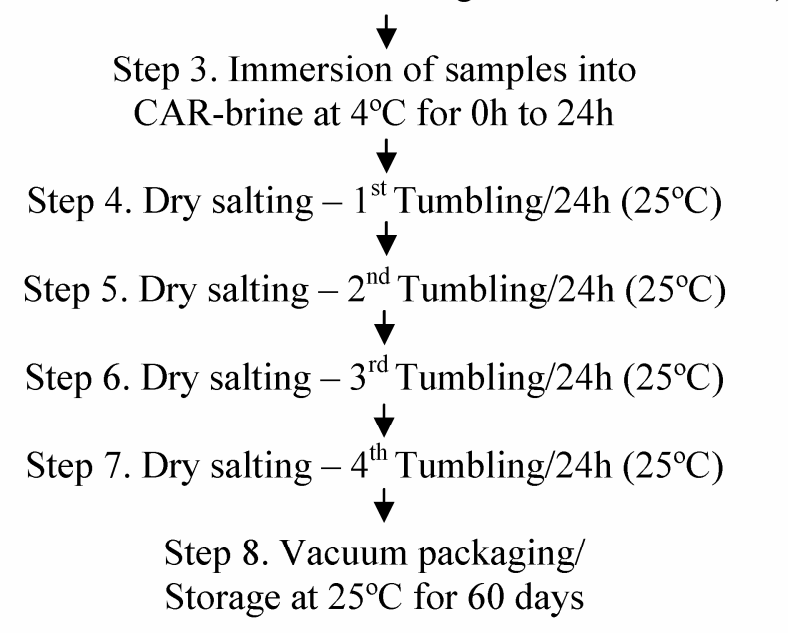

Figure 1 - Fluxogram showing step-by-step jerked beef processing injected with carrageenan in brine solution (based in Shimokomaki et al. 1998).

\section{Texture measurement}

The evaluation of shear value was carried out for the highest processing yield of the JB-CAR samples having as control CAR-free samples. This measurement was performed in uncooked salted and desalted cooked samples. The latter samples were obtained under the copiously treatment with distilled water. Then the meat pieces were packed in the propylene bags under the vacuum and subsequently cooked in a water bath until the internal temperature reached $75^{\circ} \mathrm{C}$, as measured by a Hanna thermocouple, model HI 8313 (USA). The samples were cooled down to room temperature and the meat surface was dried with absorbent paper (Youssef et al. 2007). Meat texture was measured by Warner-Bratzler shear force, using a SMS Texture Analyzer, TAXT2i model (England), linked to a microcomputer (Youssef et al. 2007). All the measurements were carried out on 10 samples in triplicate.

\section{Sensory analysis}

The samples resulting from the highest processing yield were desalted and cooked in water bath to an internal temperature of $75-78^{\circ} \mathrm{C}$, under approximately $15 \times 10 \times 10 \mathrm{~mm}$ size, cooled down to $40^{\circ} \mathrm{C}$ and submitted to a randomly selected taste panel composed of 35 panelists, familiar to the charqui products and untrained tasters. They were 12 males and 23 females of different ages. The microbiological quality of the samples was monitored following the standard methodologies according to the Brazilian legislation (Brasil 2001). Each sensory analysis was performed in an individual booth under white light where meat samples were arranged on polyethylene plate. The panelists were asked to indicate a value on a structured 9-point hedonic scale (from $1=$ dislike very much to $9=$ like very much) (Stone and Sidel, 1993).

\section{Total microbial counts}

Total aerobic colony counts were determined in order to observe the effect of processing and storage on the JB-CAR microbiological safety. The samples obtained from the higher processing yield were examined after $0,4,30$, and 60 days of storage at $25^{\circ} \mathrm{C}$ by the pour plate method using the standard plate count agar incubated at $37^{\circ} \mathrm{C}$ for 48 h (Pinto et al. 2002, Rocha-Garcia et al. 2003). The results were reported as colony-forming units 
per gram and represented the average of three counts.

\section{Statistical analysis}

Results were evaluated with Statistics for Windows 5.0 (Statsoft 1995) for the analysis of variance, multiple linear regression, Tukey's and Student's t-tests. The experimental responses for the processing yield from the factorial $2 \times 4 \times 2$ (Table 1) design were planned and analyzed with the Experimental Design of Statistica Program 5.0 (Statsoft 1995) and the model obtained was correlated to the responses of the independent variables (concentration of $\mathrm{CAR}, \mathrm{NaCl}$ and brine temperature). The program generated the response surface figures from the adjusted models.

$\underline{\text { Table } 1 \text { - Factorial design for jerked beef (JB) production using carragenan saline solutions. }}$

\begin{tabular}{cccc}
\hline Treatment & CGN $(\%)$ & NaCl(\%) & Temp $\left({ }^{\mathbf{0}} \mathbf{C}\right)$ \\
\hline 1 & 0.5 & 0 & 25 \\
2 & 0.5 & 5.0 & 25 \\
3 & 0.5 & 10.0 & 25 \\
4 & 0.5 & 15.0 & 25 \\
5 & 0.5 & 0 & 70 \\
6 & 0.5 & 5.0 & 70 \\
7 & 0.5 & 10,0 & 70 \\
8 & 0.5 & 15,0 & 70 \\
9 & 1 & 0 & 25 \\
10 & 1 & 5.0 & 25 \\
11 & 1 & 10.0 & 25 \\
12 & 1 & 15.0 & 25 \\
13 & 1 & 0 & 70 \\
14 & 1 & 5.0 & 70 \\
15 & 1 & 10.0 & 70 \\
16 & 1 & 15.0 & 70 \\
\hline
\end{tabular}

\section{RESULTS AND DISCUSSION}

Effect of CAR concentration and brine temperature on $\mathrm{JB}$ processing yield

The JB was produced in higher yields in proportion to the increase of the CAR concentrations, irrespective of the temperature of CAR-brine injected into the fresh meat (Fig. 2). The CAR has a strong interaction with water because it is able to form ionic linkages through the relatively high number of hydroxyl groups negatively charged on their ester sulfate groups (Labuza and Busk 1979). When the CAR (fractions kappa and iota) was heated to approximately 70 and $58^{\circ} \mathrm{C}$, respectively, and then allowed to cool down to ambient temperature, the formed gel retained water in its molecular structure, giving rise to the increase in the processing yield of meat products (Bater et al. 1993), although the use of cold CAR solution reported in other works demonstrated its waterholding capacity (Defreitas et al. 1997).

Increasing concentrations of the CAR and $\mathrm{NaCl}$ injected into the fresh meat increased the JB processing yield (Fig.3). Results indicated that there were positive interactions between the injected $\mathrm{CAR}$ and $\mathrm{NaCl}$, thus the processing yield. Injected CAR concentrations of approximately $1.0 \%$ dissolved in $15.0 \%$ brine drastically reduced the weight losses during the processing steps, maintaining the JB mass near $100 \%$ of its original raw material value.

Other reports have stated that the CAR capacity to hold the water within a meat product is influenced by the ions present at the meat matrix milieu (Bernal et al. 1987). The solubility properties of myofibril proteins in saline solution, particularly myosin and actin, influence the water holding capacity and subsequently the processing yield and texture of meat products (Smith 1988). Lower salt concentrations increase the myofibril proteins solubility, depending on the temperature and $\mathrm{pH}$ of the solution originating the salting in phenomena because of electrostatic effects stabilizing the charged groups at proteins surface (Samejima et al. 1992). The increase of the JB yield processing by the injection of higher $\mathrm{NaCl}$ and $\mathrm{CAR}$ concentrations was the consequence of dynamic biochemical interactions between $\mathrm{NaCl}$, soluble meat proteins and hydrocolloids. 

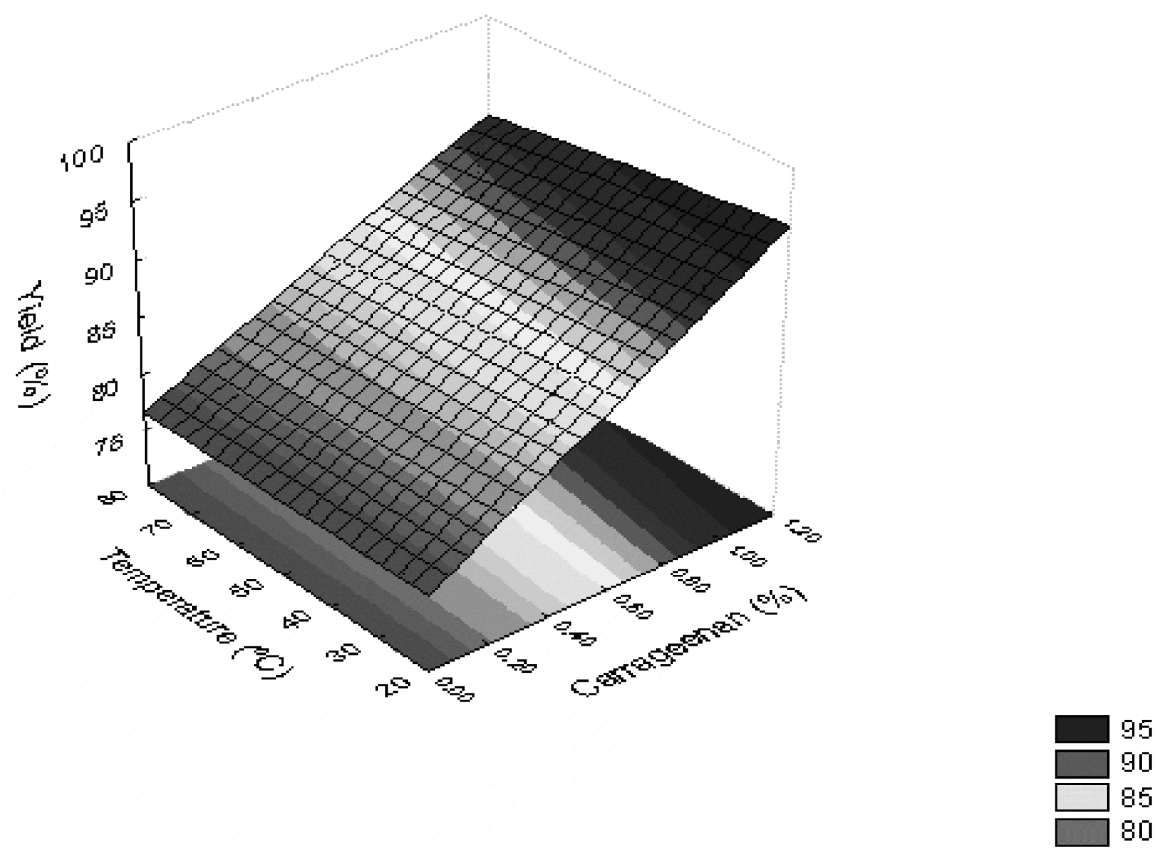

Figure 2 - Processing yield of jerked beef production to carrageenan concentration and temperature at $7.5 \% \mathrm{NaCl}$ in brine.

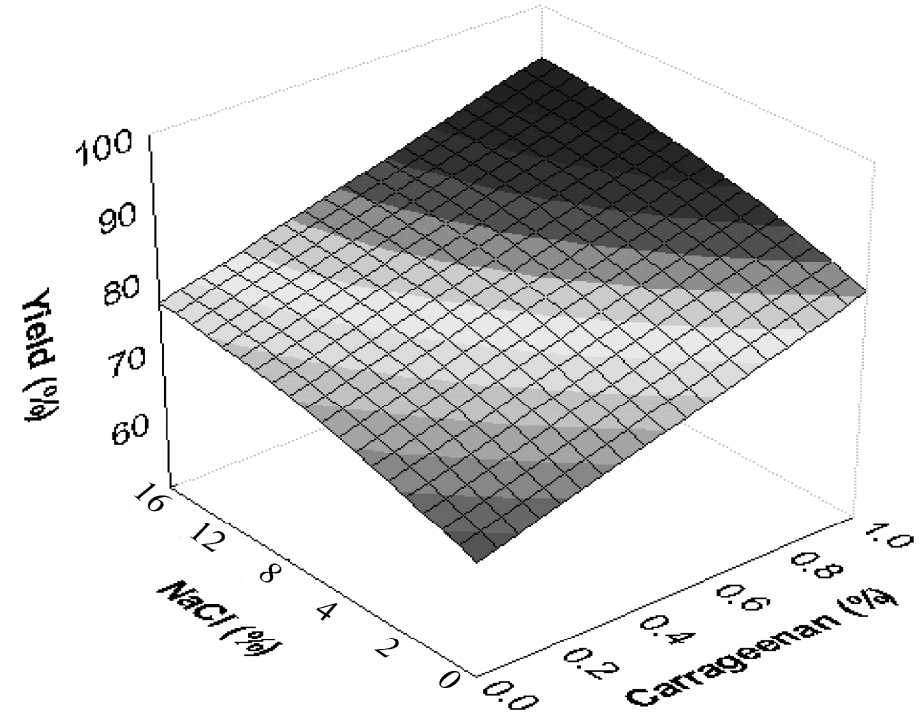

Figure 3 - Processing yield of jerked beef production in relation to $\mathrm{NaCl}$ and carrageenan concentration in brine.

Effect of CAR-brine immersion time of raw material on JB processing yield

Figure 4 shows the increase of processing yield according to the contact time between the raw material and the injected CAR-brine. The equilibrium among the protein, $\mathrm{NaCl}$, hydrocolloids and water was reached after approximately $12 \mathrm{~h}$ in the CAR-brine injected when the yield reached a value above $90.0 \%$. Apparently the presence of the CAR quantitatively altered this equilibrium, since there was significantly more water and ash and conversely less protein (Table 1). 


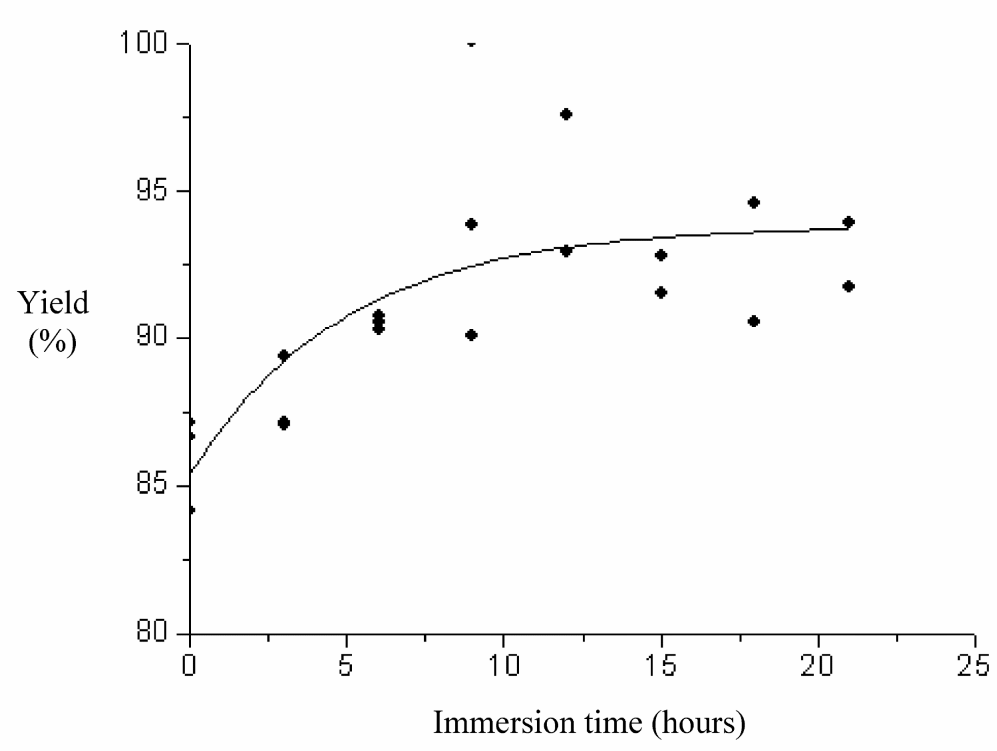

Figure 4 - Jerked beef processing yield versus immersion time in CAR-brine at $25^{\circ} \mathrm{C}(\mathrm{NaCl} 15.0 \%+$ CAR $1.0 \%$ ).

Processing yield and chemical composition of jerked beef processed with carrageenan

Table 2 shows the proximate chemical composition of samples of the JB injected with $1.0 \%$ carrageenan, dissolved in $15 \%$ brine at $25^{\circ} \mathrm{C}$, and kept immersed at $4^{\circ} \mathrm{C}\left( \pm 1^{\circ} \mathrm{C}\right)$ for $12 \mathrm{~h}$. Salting caused a reduction of $\mathrm{pH}$ and it was not influenced by the carrageenan. The JB-CAR sample contained approximately $15 \%$ more moisture and ash than the control; however, the higher saline concentration reached higher $\mathrm{NaCl}$ concentration (19.77\%), as allowed by the JB legislation (18.3\%) and its use substantially reduced the processing loss, keeping the raw meat and JB at similar quantitative mass levels, while the control samples showed a loss of approximately $25 \%$ in weight.
The use of the CAR resulted in the JB yield approximately $32 \%$ higher than the control. With the increase of water and ash, proportionally there was a decrease in the protein and lipid fraction of approximately 25 and $10 \%$, respectively in the JB samples.

These results were in agreement to those reported by Egbert et al. (1991) for the hamburgers injected with $0.5 \%$ CAR and $10 \%$ water, increasing their moisture by $15 \%$ in relation to the raw material. This particular functional property of water retention capacity by the CAR in meat products has been described as a fat substitute in the production of low-fat meat products (Candogan and Kolsarici 2003; Keeton 1994).

Table 2 - Processing yield and chemical composition of Jerked beef (JB) injected with $\mathrm{NaCl}(15.0 \%)$ and $1 \%$ carrageenan (CAR).

\begin{tabular}{cccc}
\hline & Raw material $(\%)$ & JB $(\%)$ & Jerked beef + CAR (\%) \\
\hline Yield & 100.0 & $72.96^{\mathrm{b}}( \pm 2)$ & $96.93^{\mathrm{a}}( \pm 3.04)$ \\
pH & $5.97^{\mathrm{a}}$ & $5.90^{\mathrm{b}}$ & $5.90^{\mathrm{b}}$ \\
Moisture & $74.04^{\mathrm{a}}( \pm 0.07)$ & $48.99^{\mathrm{c}}( \pm 0.62)$ & $54.83^{\mathrm{b}}( \pm 0.49)$ \\
Ash & $0.95^{\mathrm{c}}( \pm 0.06)$ & $17.91^{\mathrm{b}}( \pm 0.45)$ & $19.77^{\mathrm{a}}( \pm 0.54)$ \\
Protein & $21.75^{\mathrm{b}}( \pm 0.47)$ & $28.49^{\mathrm{a}}( \pm 1.28)$ & $21.2^{\mathrm{b}}( \pm 1.01)$ \\
Lipid & $2.9^{\mathrm{a}}( \pm 0.53)$ & $4.55^{\mathrm{a}}( \pm 1.06)$ & $4.05^{\mathrm{a}}( \pm 0.47)$ \\
\hline
\end{tabular}

${ }^{\mathrm{a}, \mathrm{b}}$ Average under similar letters on the same line did not present significant differences at the level of $5.0 \%$ by the Tukey test. 
Monitoring water activity, moisture, and ash values throughout Jerked beef processing

The values for the moisture, water activity, and ash in the JB-CAR (injected with $15 \% \mathrm{NaCl}+$ $1.0 \% \mathrm{CGN} / 25^{\circ} \mathrm{C}$ ) reached a stable value after the third day of dry salting (Table 3). Similar results were observed previously for the JB without CAR (Youssef et al. 2007; Torres et al. 1994). In charqui meat, the consequence of equilibrium established among the three components, salt:protein:water, was the final constant value of $\mathrm{a}_{\mathrm{w}}$ of approximately 0.75 , regardless of whether more salting or processing time was added
(Shimokomaki et al. 1998). A similar result was observed when the CAR was added, although more water molecules were introduced in the meat system. In order to follow the equilibrium within these components, the water molecules must chemically be associated to the CAR.

Although there were higher moisture values in JBCAR product, the $\mathrm{a}_{\mathrm{w}}$ value was constant at 0.76 , classifying this product as an intermediatemoisture meat product. Along with $\mathrm{NaCl}$, sodium nitrite, and temperature, $\mathrm{a}_{\mathrm{w}}$ is another hurdle for the growth of pathogenic microorganisms in JB (Shimokomaki et al. 1998).

Table 3 - Water activity $\left(\mathrm{a}_{\mathrm{w}}\right)$, moisture and ash determination step by step throughout berked beef processing with $1.0 \%$ carrageenan (CAR).

\begin{tabular}{ccccc}
\hline Processing steps & Time (h) & $\mathbf{a}_{\mathbf{w}}$ & Moisture (\%) & Ash (\%) \\
\hline Raw material & 0 & $0.99( \pm 0.01)$ & $76.4( \pm 0.1)$ & $1.1( \pm 0.1)$ \\
CAR-brine injection & 0 & $0.97( \pm 0.01)$ & $76.9( \pm 0.1)$ & $4.8( \pm 0.6)$ \\
Immersion in CAR-brine solution & 12 & $0.96( \pm 0.01)$ & $76.5( \pm 0.1)$ & $5.6( \pm 0.3)$ \\
Dry Salting (24h) & 34 & $0.78( \pm 0.01)$ & $61.0( \pm 0.5)$ & $18.3( \pm 0.6)$ \\
Dry Salting (48h) & 58 & $0.78( \pm 0.01)$ & $55.8( \pm 0.3)$ & $19.6( \pm 0.3)$ \\
Dry Salting (72h) & 82 & $0.76( \pm 0.01)$ & $55.5( \pm 0.1)$ & $20.6( \pm 0.4)$ \\
Dry Salting (96h) & 106 & $0.76( \pm 0.01)$ & $54.9( \pm 0.4)$ & $20.3( \pm 0.1)$ \\
\hline
\end{tabular}

( ) Standard deviation

\section{JB-CAR texture measurement}

The presence of CAR significantly improved the tenderness in both salted uncooked and desalted cooked samples. In the former samples treatment, the results obtained were $131( \pm 2) \mathrm{N}$ and $124( \pm 3)$ $\mathrm{N}$ for the control and JB-CAR CAR (injected with $15 \% \mathrm{NaCl}+1.0 \% \mathrm{CGN} / 25^{\circ} \mathrm{C}$ ), respectively, thus approximately $5.0 \%$ more tender than the control samples. For the latter samples, the result was 113 $( \pm 2) \mathrm{N}$ for the control, whereas the JB-CAR $(92 \pm 2 \mathrm{~N})$ was approximately $20 \%$ more tender and, in fact, it was the most tender among all the samples tested in this study. These results confirmed the previous study by Youssef et al. (2007) that showed that the texture in intermediate moisture meat products was mostly influenced by the moisture and myofibrils proteins contents in comparison to the collagen concentration and its crosslinks.

\section{Sensory analysis}

The acceptance level of the taste panel was approximately $80 \%$ for the cooked JB-CAR (injected with $15 \% \mathrm{NaCl}+1.0 \% \mathrm{CGN} / 25^{\circ} \mathrm{C}$ ), where a score of 9 on the hedonic scale was $100 \%$. Only $13 \%$ of panelists indicated non-approval of the product with grades lower than 4 . This result was in agreement with the works reported for other meat products such as hamburgers, sausages, hams, and meatballs that used CAR to improve their taste and texture (Candogan and Kolsarici 2003; Trius et al. 1994). The CAR application in the charqui processing is an innovation technology capable of improving its texture and higher yielding without compromising the product sensory acceptance.

\section{Total microbial counts}

Total microbial counts decreased significantly from 5.9. $\log \mathrm{CFU}$ at 0 day to $2.9 \log \mathrm{CFU}$ after 4 days of processing and then this value was constant throughout 60 days of storage. Similar results were obtained for the meat from the salted and dried hen meat, which was shown to be a safe product for microbial safety (Rocha-Garcia et al. 2003). Salted and dried JB-CAR application is a hurdle technology meat product similarly to the charqui meat (Lara et al. 2003, Shimokomaki et al. 2003). These results were in agreement with the assumption that the introduction of the CAR to this product increased the proportion of water 
intramuscularly without quantitatively affecting its $a_{\mathrm{w}}$ value.

\section{CONCLUSION}

The application of carrageenan to the intermediate-moisture meat products such as the tropical jerked beef could be beneficial, promoting an increase in the processing yield and improving the product texture by changing the functional properties without compromising its microbiological stability and sensorial acceptation. It could be considered as an innovative technology to improve the handmade technique currently used to produce the charqui meat products.

\section{REFERENCES}

AOAC. Official Methods of Analysis of AOAC International. 16ed. Arlington: AOAC, 1995.

Bater R, Descamps O, Maurer AJ. Quality characteristics of cured turkey thigh meat with added hydrocolloids. Poult Sci. 1993; 72: 349-354.

Bernal VM, Smajda CH, Smith JL, Stanley, DW. Interactions in protein/polysaccharide/calcium gels. $J$ Food Sci. 1987; 52: 1121-1125.

BRASIL. (2000), Instrução Normativa/MA n. 22, de 31 de Julho de 2000. Diário Oficial da União, Brasília, DF, Pub. 03 de agosto de 2000. Seção 1, n. 16, p. 15 25.

BRASIL. (2001), Resolução RDC ANVISA/MS n. 12, de 02 de janeiro de 2001. Regulamento Técnico sobre os Padrões Microbiológicos para Alimentos. Diário Oficial da União, Brasília, DF, 10 jan. 2001. Seção 1.

Candogan K, Kolsarici N. The effects of carrageenan and pectin on some quality characteristics of low-fat beef frankfurters. Meat Sci. 2003; 64:199-206.

Defreitas Z, Sebranek JG, Olson DG, Carr JM. Carrageenan effects on salt-soluble meat proteins in model systems. J Food Sci. 1997; 62: 539-543.

Egbert WR, Huffman DL, Chen C, Dylewski DP. Development of low-fat ground beef. Food Technol. 1991; 45: 64-73.

Giese, J. Developing low-fat meat products. Food Technol. 1992; 46: 100-108.

Keeton JT. Low-fat meat products-technological problems with processing. Meat Sci. 1994; 36: 261276.

Labuza TP, Busk GG. An analysis of water binding in gels. J Food Sci. 1979; 44: 1379-1385.
Lara JAF, Senigalia SWB, Oliveira TCR, Dutra IS, Pinto MF, Shimokomaki M. Evaluation of survival of Staphylococcus aureus and Clostridium botulinum in charqui meats. Meat Sci. 2003; 65: 609 -613.

Leistner L, Gorris LGM. Food preservation by hurdle technology. Trends Food Sci Technol. 1995; 6: 4146.

Pinto MF, Ponzano EHG, Franco BDGM, Shimokomaki M. Charqui meats as fermented meat products:role of bacteria for some sensorial properties development. Meat Sci. 2002; 61: 187-191.

Rocha-Garcia CE, Youssef EY, Souza NE, Matsushita M, Figueiredo E, Shimokomaki M. Preservation of spent leghorn hen meat by a drying and salting process. J Appl Poult Res. 2003; 12: 335-340.

Samejima K, Lee NH, Ishioroshi M. Protein extractability and thermal gel formability of myofibrils isolated from skeletal and cardiac muscle at different post mortem periods. J Sci Food Agric.1992; 58: 385-393.

Shimokomaki M, Franco BDG, Biscontini TM, Pinto MF, Ponzano EHG, Terra NN, Zorn TMT. Charqui meats are hurdle technology meat products. Food Rev Int. 1998; 14: 339-349.

Shimokomaki M, Youssef EY, Terra NN. Curing. In: Caballero B, Trugo L, Finglas PM, editors. Encyclopedia of Food Sciences and Nutrition. London: Elsevier; 2003. p. 1702-1708.

Smith DM. Meat proteins: functional properties in comminuted meat products. Food Technol. 1988; 42: 116-121.

STATSOFT, Inc., 1995. STATISTIC for Windows (Computer program manual). Tulsa, Oklahoma, USA.

Stone H, Sidel JL. Sensory evaluation practices. 2nd ed. New York: Academic Press, 1993.

Torres EAFS, Shimokomaki M, Franco BDGM, Landgraf M. Parameters determining the quality of charqui, an intermediate moisture meat product. Meat Sci. 1994; 38: 229-234.

Trius A, Sebranek JG, Rust RE, Carr J.M. Low-fat bologna and beaker sausage: Effects of carrageenans and chloride salts. J Food Sci. 1994; 59: 941-945.

Youssef EY, Rocha-Garcia CE, Yamashita F, Shimokomaki M. Chemical Basis for Beef Charqui Meat Texture. Braz Arch Biol Technol, 2007; 50: 719-724. 